\title{
Obituary
}

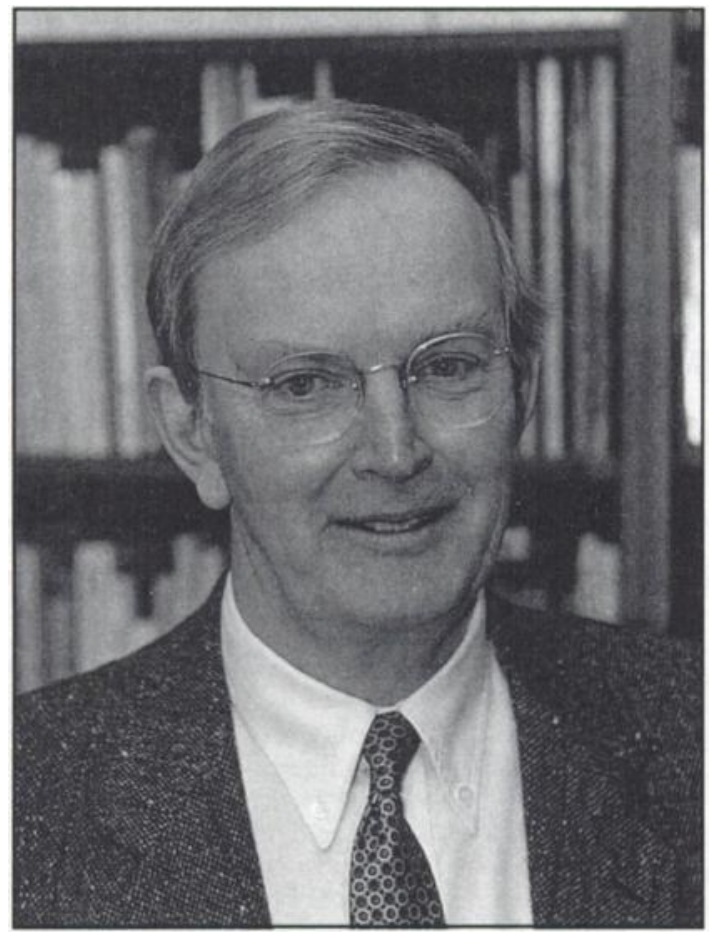

William Lywelyn Parry-Jones, formerly Professor of Psychiatry. Child and Adolescent Psychiatry, Royal Hospital For Sick Children, Glasgow.

We must mourn the death on 20 July 1997 , of a loved and valued friend and celebrate his life. Having trained at Cambridge and the London Hospital, being awarded an MD by the University of Cambridge in 1969, William ParryJones undertook specialist training and became a university lecturer in Oxford. For the past decade he has been the only professor of child and adolescent psychiatry in Scotland. He took up his post at the Department of Child and Adolescent Psychiatry at the University of Glasgow in 1987, leaving behind him a valued career as consultant in charge of the Highfield Adolescent Unit, Warneford Hospital, Oxford. He remained a Fellow of Linacre College of that city.
In his new post, he kept up a wide range of research and clinical interests, particularly adolescent health care and with his wife, Brenda, a distinguished historical researcher, worked on the history of psychiatry with particular reference to childhood and adolescence.

In Scotland he made major innovations in undergraduate and postgraduate training and liaison services for children and adolescents. He was adviser to the Scottish Office on mental health issues and Chairman of the Child and Adolescent Psychiatry Section of the Scottish Division of the College. He was a Research Associate of the Wellcome Unit for the History of Medicine and Visiting Fellow to Gonville and Caius College, Cambridge.

The Lockerbie air disaster of 1988 provided a tragic impetus towards the study of the psychological traumatisation of children and young people involved in disasters. This focus led to valued interaction between the department at Yorkhill, Glasgow, and others engaged in this field in the UK and internationally.

Special interest developed in the effects of war and displacement on children and adolescents and William's international achievements during the last seven years will continue to bear fruit. He played a leading role in developing child and adolescent psychiatric services in Eastern Europe, including teaching, organisation and advisory activities, with particular reference to Hungary and the five republics of former Yugoslavia. In this he has been supported by a number of international organisations, including the World Health Organization, the British Council, EC TEMPUS and UNICEF.

Up to the time of his death. William was a UNICEF consultant to the former Yugoslavia, and had undertaken a number of strategy reviews of services for refugees and vulnerable children, a report on the welfare of children without parents or parental care, and was helping to evaluate UNICEF-funded projects throughout the war period. His British Council academic link, an interchange scheme with the World Health Organization Collaborating Centre in Child and Adolescent Health, Slovenia, was scheduled to continue until the year 2000. He contributed to the International Pediatric Association as a member of a task force on the impact of war and disaster on children. He founded the Glasgow Trauma Consultation Group whose members continue his work. 
He has, together with co-workers from his department, published intensively and extensively on these and related topics. He worked indefatigably and yet, together with Brenda, maintained and extended the medical/ historical library founded by his doctor grandfather and father. His house was open to friends and colleagues.

His work will survive him and bear fruit for others. We will remember him with respect for his scholarship and affection for his friendship and sense of fun.
William leaves his much loved wife, Brenda, three children, their spouses and three grandchildren. Our thoughts are with them.

JEAN HARRIS-HENDRIKS

\section{William Malcolm Millar}

Unfortunately, it was not possible to reproduce the photograph originally planned to accompany the obituary of William Malcolm Millar (Psychiatric Bulletin, November 1997, 21, 733-734) and we regret we omitted to alter the text accordingly. 